\title{
PROYEKSI PENYERAPAN TENAGA KERJA PERIKANAN BERDASARKAN FAKTOR INDUSTRIALISASI MENGGUNAKAN METODE FUNGSI TRANSFER
}

\author{
Yulinda Nurul Aeni ${ }^{1}$ \\ Pusat Penelitian Kependudukan - Lembaga Ilmu Pengetahuan Indonesia (P2K-LIPI) \\ e-mail: 1yulindaaini@gmail.com
}

\begin{abstract}
Abstrak
FAO menempatkan Indonesia sebagai negara dengan potensi perikanan terbesar di dunia, namun potensi tersebut belum dimanfaatkan dengan optimal. Pemerintah telah membentuk program industrialisasi perikanan, namun pelaksanaannya yang belum terimplementasi dengan baik menyebabkan penyerapan tenaga kerja di sektor ini masih rendah. Penelitian ini akan membentuk proyeksi penyerapan tenaga kerja subsektor perikanan 2019-2024 menggunakan metode fungsi transfer dengan mempertimbangkan faktor industrialisasi perikanan sebagai prediktor terhadap indeks elastisitas penyerapan tenaga kerja perikanan. Industrialisasi perikanan diukur berdasarkan faktor perkembangan investasi dan pertumbuhan jumlah perusahaan perikanan. Hasil proyeksi menunjukkan bahwa industrialisasi perikanan di tahun mendatang belum mampu mendorong respon pertumbuhan penyerapan tenaga kerja subsektor perikanan.
\end{abstract}

Kata kunci: fungsi transfer, industrialisasi, perikanan, proyeksi, tenaga kerja

\begin{abstract}
FAO places Indonesia as the country with the largest fishery potential in the world, but this potential has not been utilized optimally. The government had established a fisheries industrialization, but this program had not been implemented properly, resulting in low employment in this sector. This research would form projections of labor absorption in the fisheries subsector 2019-2024 using the transfer function method by considering the factor of fisheries industrialization as a predictor of the fisheries labor absorption elasticity index. The industrialization of fisheries is measured based on investment development factors and growth in the number of fishing companies. The projection results showed that the industrialization of fisheries in the coming year had not been able to encourage a response to the growth of labor absorption in the fisheries subsector.
\end{abstract}

Keywords: transfer function, industrialization, fisheries, projection, labor 


\section{PENDAHULUAN}

Sumber daya perikanan laut Indonesia tersebar di perairan wilayah Indonesia dan perairan Zona Ekonomi Eksklusif Indonesia (ZEEI) yang terbagi dalam sembilan Wilayah Pengelolaan Perikanan (KKP, 2015) dengan rincian pada Gambar 1 berikut.

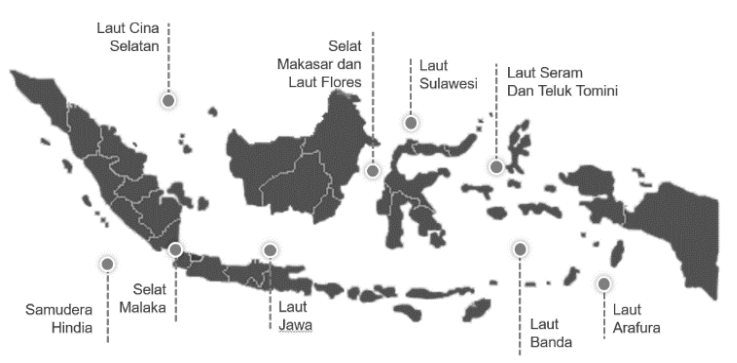

Gambar 1. Wilayah Pengelolaan Perikanan (WPP) di Indonesia

Posisinya yang dikelilingi lautan, menjadikan potensi subsektor perikanan Indonesia melimpah sehingga subsektor ini menjadi salah satu subsektor yang menjanjikan bagi perekonomian Indonesia. Bahkan pada tahun 2012, Food Agriculture Organization (FAO) menempatkan Indonesia sebagai negara dengan potensi perikanan terbesar di dunia (FAO, 2012).

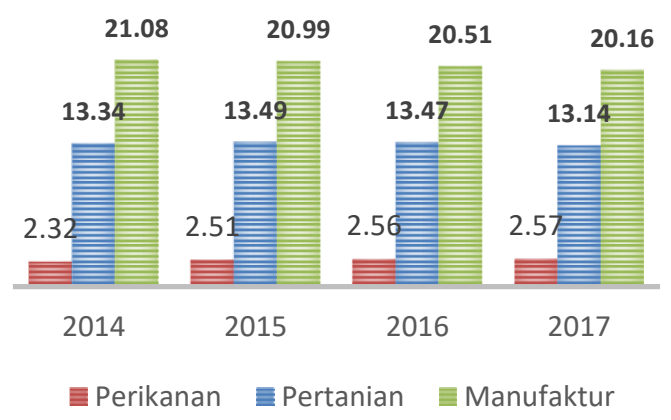

Gambar 2. Distribusi PDB Perikanan, Pertanian, dan Manufaktur 2014-2017 (Persen)

Namun, permasalahan utama dari negeri yang $75 \%$ wilayahnya berupa lautan ini adalah kesenjangan antara potensi besar tersebut dengan kemampuan memanfaatkan secara optimal. Dengan potensi perikanan yang mencapai 68 juta ton pertahun, hanya $35 \%$ yang bisa dimanfaatkan (Pusat Data Statistik dan Informasi, Kelautan dan
Perikanan Dalam Angka 2018, 2018). Hal ini menjadikan subsektor perikanan memiliki kontribusi relatif rendah terhadap PDB, yaitu 2,57\% di tahun 2017 (Gambar 2). Angka ini jauh lebih rendah dibanding kontribusi subsektor lain seperti pertanian yang menyumbang PDB sebesar 13,14\% dan manufaktur 20,16\% (BPS, Produk Domestik Bruto (PDB) Atas Dasar Harga Konstan Menurut Lapangan Usaha, 2017).

Salah satu faktor penyebab pemanfaatan potensi perikanan di Indonesia yang belum optimal adalah karena rendahnya kualitas dan kuantitas produksi yang dihasilkan oleh nelayan yang disebabkan oleh aksesibilitas dan ketersediaan infrastruktur yang belum memadai. Di sisi lain, prosedur pelayanan perizinan usaha yang dianggap sulit membuat minimnya investasi di subsektor ini sehingga membuat industri sulit bangikit (Mariza, Wicaksono, dn Octavia, 2016)

Pemanfaatan potensi perikanan yang belum optimal menjadi penghambat pemerintah yang di tahun 2014 telah membentuk program untuk menjadikan Indonesia sebagai poros maritim dunia (Kominfo, 2018). Selanjutnya, pemerintah menurunkan berbagai kebijakan dalam program-program aksi, salah satunya adalah pelaksanaan industrialisasi kelautan dan perikanan yang bertujuan untuk mempercepat pembangunan subsektor kelautan dan perikanan di Indonesia (KKP, 2012). Tidak lanjut dari kebijakan tersebut, pemerintah mengeluarkan rencana aksi percepatan pembangunan industri perikanan nasional melalui Peraturan Presiden No.3 Tahun 2017. Dalam pelaksanaanya, rencana aksi tersebut belum terimplementasi dengan efektif karena sedikitnya program nyata pemerintah untuk merealisasikan isi yang tertuang dalam perpres tersebut. Padahal apabila pemerintah memberikan perhatian yang serius, subsektor ini akan memberikan kontribusi yang lebih besar terhadap pembangunan ekonomi, terutama untuk masyarakat nelayan dan petani ikan, serta dapat menyerap tenaga kerja lebih banyak (Subri, 2007). 
Dalam aspek ketenagakerjaan, dengan pertumbuhan ekonomi yang kurang dari 5\%, hanya sekitar 15 juta tenaga kerja yang terserap. Subsektor ini baru berkontribusi sebesar $13,1 \%$ terhadap total jumlah tenaga kerja di semua subsektor yang pada akhir 2015 tercatat sebanyak 114,8 juta orang. Jumlah tersebut relatif kecil dibanding kontribusi subsektor lain, seperti pertanian yang menyerap sebanyak 37,75 juta tenaga kerja $(32,88 \%)$ (BPS, 2015). Selain itu, jumlah nelayan dan rumah tangga perikanan (RTP) juga mengalami pertumbuhan yang kurang signifikan. Dari tahun 2010-2014, pertumbuhan tenaga kerja di subsubsektor perikanan tangkap hanya sebesar $1,045 \%$ dengan kenaikan jumlah tenaga kerja sebanyak 119 ribu nelayan. Angka ini tidak jauh berbeda dengan subsubsektor perikanan budidaya yang mengalami pertumbuhan tenaga kerja sebesar 1,20\% dari tahun 2010-2014 dengan kenaikan jumlah tenaga kerja sebanyak 648,5 ribu pembudidaya (KKP, 2015).

Terdapat beberapa penelitian yang membahas mengenai industrialisasi perikanan, diantaranya adalah penelitian yang dilakukan oleh Poernomo dan Heruwati (2011) mengenai dampak positif dan negatif pelaksanaan program industrialisasi perikanan dan penelitian oleh Huda, dkk (2015) mengenai industrialisasi perikanan dalam pengembangan wilayah Jawa Timur. Penelitian-penelitian tersebut lebih banyak membahas mengenai pelaksanaan industrialisasi perikanan, namun masih sedikit yang membahas mengenai dampaknya terhadap penyerapan tenaga kerja di sektor tersebut. Karena itu, penelitian ini akan membahas mengenai penyerapan tenaga kerja berdasarkan faktor industrialisasi.

Berdasarkan latar belakang di atas, penelitian ini bertujuan untuk membuat proyeksi penyerapan tenaga kerja subsektor perikanan dalam lingkup nasional tahun 2019-2024 berdasarkan faktor industrialisasi perikanan. Proyeksi digunakan untuk melihat pengaruh perkembangan jumlah investasi dan jumlah perusahaan perikanan dalam meramalkan penyerapan tenaga kerja subsektor perikanan nasional. Proyeksi tenaga kerja perikanan yang tepat diperlukan oleh pengambil kebijakan untuk memperkirakan penyerapan tenaga kerja di masa depan sehingga pemanfaatan potensi perikanan di Indonesia akan optimal dan mendukung kebijakan program-program pembangunan sektor perikanan.

\section{METODOLOGI PENELITIAN}

\section{Konsep dan Definisi}

Rao

Berikut merupakan beberapa konsep dan definisi variabel yang digunakan dalam penelitian.

a. Menurut KKP (2015), penyerapan tenaga kerja pada subsektor perikanan dibagi pada kegiatan perikanan tangkap, perikanan budidaya, pengolahan, dan pemasaran, serta jasa penunjang lainnya yang meliputi tenaga kerja yang terlibat pada program-program pemberdayaan di subsektor perikanan.

b. Elastisitas penyerapan tenaga kerja merupakan rasio dari jumlah tenaga kerja dan PDB subsektor perikanan nasional (Dumairy, 2004). Data PDB yang digunakan adalah PDB atas dasar harga konstan tahun 2000 karena telah menghilangkan pengaruh inflasi sehingga angka yang dihasilkan mencerminkan pertumbuhan riil.

c. Industrialisasi subsektor perikanan sebagai prediktor diproksi menggunakan variabel pertumbuhan jumlah perusahaan dan perkembangan investasi perikanan nansional. Adapun perkembangan jumlah investasi dihitung dari akumulasi Penanaman Modal Asing (PMA) dan Penanaman Modal Dalam Negeri (PMDN).

\section{Jenis dan Sumber Data}

Penelitian ini menggunakan data sekunder berupa data time series tahun 2000-2016. Keterangan mengenai nama variabel, sumber, tipe dan skala data ditampilkan pada Tabel 1 berikut. 
Tabel 1. Jenis dan Sumber Data Penelitian

\begin{tabular}{|l|l|l|}
\hline \multicolumn{1}{|c|}{ 1. Nama Variabel } & \multicolumn{1}{|c|}{ 2. Sumber Data } & \multicolumn{1}{|c|}{$\begin{array}{c}\text { Tipe, Skala } \\
\text { Data }\end{array}$} \\
\hline $\begin{array}{l}\text { Tenaga Kerja Subsektor Perikanan Nasional } \\
\text { Tahun 2000-2016 (Juta Orang) }\end{array}$ & $\begin{array}{l}\text { Dirjen Perikanan Tangkap dan Perikanan } \\
\text { Budidaya Kementerian Kelautan dna } \\
\text { Perikanan (KKP) }\end{array}$ & $\begin{array}{l}\text { Numerik, } \\
\text { Rasio }\end{array}$ \\
\hline $\begin{array}{l}\text { Produk Domestik Bruto (PDB) Subsektor } \\
\text { Perikanan Nasional 2000-2016 (\%) }\end{array}$ & Badan Pusat Statistik (BPS) & $\begin{array}{l}\text { Numerik, } \\
\text { Rasio }\end{array}$ \\
\hline $\begin{array}{l}\text { Perkembangan Investasi Subsektor } \\
\begin{array}{l}\text { Perikanan Nasional Tahun 2000-2016 (Juta } \\
\text { Rupiah) }\end{array}\end{array}$ & $\begin{array}{l}\text { National Single Windows of Investment (NSWI), } \\
\text { Badan Koordinasi Penanaman Modal (BKPM }\end{array}$ & $\begin{array}{l}\text { Numerik, } \\
\text { Rasio }\end{array}$ \\
\hline $\begin{array}{l}\text { Pertumbuhan Jumlah Perusahaan Perikanan } \\
\text { 2000-2016 (Instansi) }\end{array}$ & Badan Pusat Statistik (BPS) & $\begin{array}{l}\text { Numerik, } \\
\text { Rasio }\end{array}$ \\
\hline
\end{tabular}

\section{Metode Analisis}

Penelitian mengenai proyeksi penyerapan tenaga kerja pernah dilakukan oleh Kementerian Pertanian untuk tahun 2013-2019 menggunakan metode Moving average (MA) dan geometri (Pusat Data dan Informasi Pertanian, 2013). Selain itu, proyeksi ketenagakerjaan juga pernah dilakukan menggunakan metode pertumbuhan eksponensial dan fungsi derivasi Cobb-Douglas 2 input (Junaidi dan Zulfanetti, 2016). Penelitian lain mengenai proyeksi tenaga kerja menggunakan metode geometri dan ekstrapolasi juga pernah dilakukan. Penelitian ini mengasumsikan bahwa pertumbuhan dan elastisitas penyerapan tenaga kerja tidak berubah dari tahun ke tahun (Kumalasari, 2012). Dari beberapa penelitian tersebut, metode yang paling banyak digunakan adalah metode deterministik. Hanya sedikit penelitian yang menggunakan metode probabilistik berdasarkan pola dan karakteristik data serta melihat pengaruh dari variabel lain yang mungkin mempengaruhi, seperti metode fungsi transfer. Untuk itu, dalam penelitian ini, akan digunakan metode fungsi transfer dengan melihat pengaruh industrialisasi perikanan terhadap penyerapan tenaga kerja.

Fungsi transfer merupakan gabungan dari model Autoregressive Integrated Moving average (ARIMA) univariate dan analisis regresi berganda sehingga menjadi satu model yang mencampurkan pendekatan deret berkala dengan pendekatan kausal. Seluruh sistem tersebut adalah sistem yang dinamis, dengan kata lain deret input memberikan pengaruhnya kepada deret output melalui fungsi transfer (Makridakis, 1999). Pemodelan dilakukan secara serentak menggunakan deret input perkembangan jumlah perusahaan perikanan dan jumlah investasi terhadap elastisitas penyerapan tenaga kerja, sehingga model fungsi transfer yang digunakan adalah multi input.

Berikut merupakan langkah analisis dalam membentuk pemodelan fungsi transfer multi input (Wei, 2006).

1. Mengidentifikasi deret input dan output.

2. Uji stasioneritas mean menggunakan uji Augmented Dickey Fuller dan uji stasioneritas varians menggunakan BoxCox Transformation. Jika deret input atau deret output belum stasioner dalam varians maka dilakukan transformasi, dan jika belum stasioner dalam mean akan dilakukan differencing. Deret data yang telah stasioner disebut $x_{t}$ dan $y_{t}$.

3. Identifikasi model ARIMA untuk seluruh deret input dengan melihat plot Auto-Correlation Function (ACF) dan Partial Auto-Correlation Function (PACF) untuk mengetahui lag yang signifikan dan ada/tidaknya periode musiman, sehingga orde model ARIMA dapat diketahui (Tabel 2).

4. Uji signifikansi parameter model ARIMA.

5. Uji asumsi residual yang meliputi uji white noise dan uji normalitas.

6. Pemilihan model ARIMA terbaik berdasarkan nilai Root Mean Square Error (RMSE) dan Mean Absolute Persentage Error (MAPE) terkecil, serta nilai $R$-squared tertinggi. 
Tabel 2. Karakteristik Plot ACF dan PACF

\begin{tabular}{|c|l|l}
\hline Proses & \multicolumn{1}{|c|}{ ACF } & \multicolumn{1}{c}{ PACF } \\
\hline AR $(p)$ & $\begin{array}{l}\text { Garis } \\
\text { cenderung } \\
\text { turun cepat } \\
\text { mengikuti } \\
\text { pola } \\
\text { gelombang } \\
\text { sinus }\end{array}$ & $\begin{array}{l}\text { Garis terputus } \\
\text { ketika menuju } \\
\text { angka nol } \\
\text { setelah lag-p }\end{array}$ \\
\hline MA $(q)$ & $\begin{array}{l}\text { Garis terputus } \\
\text { ketika menuju } \\
\text { angka nol } \\
\text { setelah lag-p }\end{array}$ & $\begin{array}{l}\text { Garis } \\
\text { cenderung } \\
\text { turun cepat } \\
\text { mengikuti } \\
\text { pola } \\
\text { gelombang } \\
\text { sinus }\end{array}$ \\
\hline $\begin{array}{c}\text { ARIMA } \\
(p, \mathrm{~d}, q)\end{array}$ & $\begin{array}{l}\text { Garis secara } \\
\text { terus menerus } \\
\text { menuju nol }\end{array}$ & $\begin{array}{l}\text { Garis secara } \\
\text { terus menerus } \\
\text { menuju nol }\end{array}$ \\
\hline
\end{tabular}

7. Melakukan prewhitening deret input dan output untuk menghilangkan seluruh pola yang diketahui agar yang tertinggal hanya white noise.

Saat deret input dalam kondisi stasioner, maka dilanjutkan dengan penentuan model ARIMA pada deret input. Setelah model ARIMA yang sesuai untuk deret input terbentuk, maka dilakukan proses prewhitening. Model untuk deret input yang telah diprewhitening adalah sebagai berikut.

$$
\frac{\phi_{x}(B)}{\theta_{x}(B)} x_{t}=\alpha_{t}
$$

Keterangan:

$\phi_{x}$ : Parameter autoregressive deret input

$\theta_{x}$ : Parameter moving average deret input

$x_{t}$ : Deret input yang stasioner

$\alpha_{t}$ : Deret noise

Deret output dimodelkan menggunakan parameter ARIMA yang terbentuk pada deret input. Prewhitening pada deret output dilakukan dengan cara yang sama pada deret input, yaitu sebagai berikut.

$$
\frac{\phi_{y}(B)}{\theta_{y}(B)} y_{t}=\beta_{t}
$$

$\phi_{y}:$ Parameter autoregressive deret output

$\theta_{y}$ : Parameter moving average deret output

$y_{t}$ : Deret output yang stasioner

$\beta_{t}$ : Deret noise

8. Melakukan deteksi hubungan antara variabel input dan output dengan menggunakan Cross-Correlation Function (CCF).

$\mathrm{CCF}$ digunakan untuk mengukur kekuatan dan arah hubungan diantara dua variabel random $x_{t}$ (variabel input) dan $y_{t}$ (variabel output) yang masingmasing merupakan proses univariate yang stationer. Fungsi cross correlation antara $x_{t}$ dan $y_{t}$ dapat ditulis sebagai berikut.

$$
\rho_{x y}(k)=\frac{\gamma_{x y}(k)}{\sigma_{x} \sigma_{y}}
$$

Keterangan:

$\sigma_{x}:$ Standar deviasi $x_{t}$

$\sigma_{y}:$ Standar deviasi $y_{t}$

$\rho_{x y}$ : Fungsi Cross Correlation

$\gamma_{x y}:$ Covarian $x_{t}$ dan $y_{t}$

9. Identifikasi awal model fungsi transfer dengan menentukan orde model fungsi transfer $(b, r, s)$ berdasarkan plot korelasi silang.

a. Nilai $b$ menjelaskan bahwa $y_{t}$ tidak dipengaruhi oleh nilai $x_{t}$ sampai periode $t+b$, besarnya $b$ sama dengan jumlah bobot respon impuls yang tidak berbeda dari nol secara signifikan.

b. Nilai $s$ menyatakan berapa lama deret output $y_{t}$ secara terus menerus dipengaruhi oleh nilai-nilai baru dari deret input $\left(x_{t}\right) . y_{t}$ dipengaruhi oleh $x_{t+b}, \quad x_{t+b+1}, \ldots, x_{t+b+s}$, Nilai $s$ adalah jumlah bobot respon impuls sebelum terjadinya pola menurun.

c. Nilai $r$ menunjukkan bahwa $y_{t}$ berkaitan dengan nilai-nilai masa lalu dari $y_{t}$, yaitu $y_{t-1}, y_{t-2}, \ldots, y_{t-r}$. Terdapat tiga kondisi pada nilai $r$ yang mempunyai indikasi pemodelan berbeda, yaitu $r=0$, bila jumlah bobot respon impuls hanya terdiri dari beberapa lag yang kemudian 
langsung terpotong, $r=1$, bila bobot respon impuls menunjukkan suatu pola eksponensial yang menurun, dan $r=2$, bila bobot respon impuls menunjukkan suatu pola eksponensial menurun dan mengikuti pola sinusoidal.

10. Identifikasi noise function dengan melihat plot ACF dan PACF dari identifikasi awal model fungsi transfer. $n_{t}=y_{t}-$

$\sum_{j=1}^{m}\left[\delta_{j}(\beta)\right]^{-1} \omega_{j}(B)_{j, t-b_{j}}^{x}$

Keterangan:

$\delta_{j}$ dan $\omega_{j}$ : konstansa fungsi transfer

$n_{t} \quad$ : Deret noise

11. Identifikasi akhir model fungsi transfer multi input dengan mengkombinasikan model awal dan noise function.

$y_{t}=\frac{\omega_{s}(B)}{\delta_{r}(B)} x_{t-b}+\frac{\theta(B)}{\phi(B)} a_{t}$.

12. Melakukan proyeksi menggunakan model fungsi transfer multi input.

\section{HASIL ANALISIS DAN PEMBAHASAN}

\section{Industrialisasi Kelautan dan Perikanan}

Dalam teori Colin Clark \& Simon Kuznets, industrialisasi dianggap sebagai proses pertumbuhan ekonomi dalam wujud akselerasi investasi dan tabungan. Jika tabungan cukup tinggi, maka kemampuan sebuah negara untuk mengadakan investasi juga meningkat sehingga target pertumbuhan ekonomi dan penciptaan lapangan kerja lebih mungkin dicapai secara cepat (Hakim, 2009).

Di bidang kelautan dan perikanan, KKP telah membentuk peraturan terkait indus-trialisasi. Dalam peraturan tersebut dijelaskan bahwa industrialisasi kelautan dan perikanan merupakan integrasi sistem produksi hulu dan hilir untuk meningkatkan skala dan kualitas produksi, produktivitas, daya saing, dan nilai tambah sumber daya kelautan dan perikanan secara berkelanjutan (KKP, 2012). Industrialisasi perikanan ini bertujuan untuk meningkatkan kesejahteraan nelayan pembudidaya, pengolah, dan pemasar hasil perikanan, menyerap tenaga kerja, serta meningkatkan devisa negara. Industrialisasi perikanan ini berprinsip untuk mendorong penguatan struktur industri melalui peningkatan jumlah dan kualitas industri perikanan dan pembinaan hubungan antar entitas sesama industri pada semua tahapan rantai nilai (value chain) (Republik Indonesia, 2016). Selain itu, kebijakan industrialisasi perikanan dan investasi akan diarahkan untuk mendorong kemitraan usaha yang saling menguntungkan melalui pengembangan komoditas nasional dan produk-produk inovatif dan kompetitif di pasar global (Bappenas, 2016).

Pengembangan usaha dan investasi yang menjadi salah satu strategi pelaksanaan indus-trialisasi perikanan bertujuan untuk men-dorong kemitraan usaha yang saling meng-untungkan antara usaha skala mikro, kecil, dan menengah dengan usaha skala besar melalui pengembangan komoditas nasional dan produk-produk yang kompetitif di pasar global. Dengan pengembangan usaha dan investasi, industri/perusahaan perikanan skala kecil dan menengah diharapkan akan dapat berkembang sehingga dapat memperkuat basis industri perikanan secara nasional. Hal ini menunjukkan bahwa pelaksanaan industri-alisasi perikanan dapat diukur berdasarkan pertumbuhan jumlah perusahan/industri per-ikanan serta perkembangan investasi di sektor ini.

\section{Identifikasi Model Deret Input dan Deret Output}

1. Identifikasi Pola Variabel

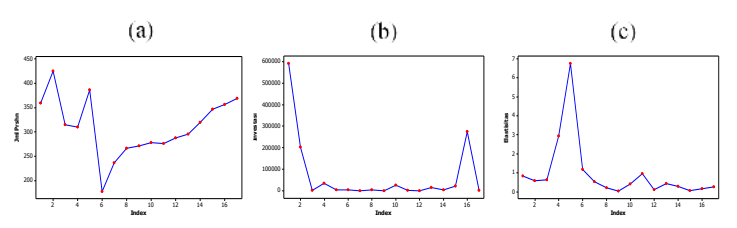

Gambar 3. Plot Time Series (a) Variabel Jumlah Perusahaan, (b) Jumlah Investasi, (c) Elastisitas Penyerapan Tenaga Kerja

Identifikasi pola variabel digunakan untuk melihat ada tidaknya pola tertentu, seperti pola musiman, tren, dan lain-lain yang nantinya akan berpengaruh terhadap model fungsi transfer yang digunakan. 
Identifikasi pola variabel menggunakan time series plot dengan hasil pada Gambar 3.

Hasil identifikasi pada Gambar 3 menunjukkan bahwa pola data untuk variabel jumlah perusahaan, jumlah investasi, dan elastisitas penyerapan tenaga kerja subsektor perikanan berfluktuasi dan tidak membentuk pola tertentu, sehingga pemilihan model fungsi transfer dalam melakukan proyeksi telah sesuai. Adapun model fungsi transfer yang digunakan adalah fungsi transfer multi input nonseasonal, karena pola data tidak mengindikasikan pola musiman.

2. Identifikasi Model Deret Input Jumlah Perusahaan

Dalam identifikasi model untuk masing-masing deret input, terdapat beberapa tahapan yang dilakukan, seperti uji stasioner means dan variances, serta penentuan dan pemilihan model ARIMA terbaik.

\begin{tabular}{|c|c|c|c|c|c|c|c|c|}
\hline \multicolumn{2}{|c|}{ Autocorrelation } & \multicolumn{2}{|c|}{ Partial Correlation } & & $A C$ & PAC & Q-Stat & Prob \\
\hline & 1 & $\square$ & 1 & & -0.445 & -0.445 & 3.8098 & 0.051 \\
\hline 10 & 1 & $\square$ & 1 & & -0.109 & -0.384 & 4.0562 & 0.132 \\
\hline & ין & 1 & 1 & 3 & 0.420 & 0.266 & 7.9727 & 0.047 \\
\hline 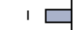 & 1 & 1 & 1 & & -0.291 & 0.031 & 10.004 & 0.040 \\
\hline 1 & 1 & 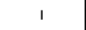 & 1 & 5 & 0.039 & 0.034 & 10.044 & 0.074 \\
\hline 1 & I & 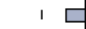 & 1 & 6 & 0.002 & -0.226 & 10.044 & 0.123 \\
\hline 1 & 1 & . & 1 & 7 & 0.015 & 0.031 & 10.052 & 0.186 \\
\hline 1 & 1 & t & 1 & & -0.026 & -0.019 & 10.076 & 0.260 \\
\hline 1 & 1 & & 1 & & -0.061 & -0.013 & 10.228 & 0.332 \\
\hline 1 & 1 & 15 & I & 10 & 0.011 & -0.176 & 10.233 & 0.420 \\
\hline 1 & 1 & 1 & I & 11 & -0.059 & -0.151 & 10.431 & 0.492 \\
\hline 1 & 1 & 10 & 1 & 12 & -0.007 & -0.101 & 10.434 & 0.578 \\
\hline
\end{tabular}

Gambar 4. Plot ACF dan PACF Deret Input Jumlah Perusahaan
Tahapan pertama adalah penentuan ordo model ARIMA berdasarkan plot ACF dan PACF pada Gambar 4. Dari identifikasi plot ACF dan PACF, jumlah lag yang signifikan pada grafik PACF sebanyak 2 $(p=2)$ dan pada grafik ACF sebanyak 1 $(\mathrm{p}=1)$. Dengan jumlah differencing sebanyak 1, maka terdapat 5 kombinasi model tentatif ARIMA yang terbentu, yaitu $(2,1,1),(2,1,0),(1,1,1),(1,1,0)$, dan $(0,1,1)$.

Selanjutnya dilakukan pengujian pada residual yang meliputi uji white noise menggunakan uji Ljung-Box dan uji normalitas menggunakan uji KolmogorovSmirnov dengan hasil pada Tabel 3 berikut.

Tabel 3 menunjukkan bahwa semua model tentatif ARIMA memiliki nilai $p$ value lebih dari taraf sinifikansi 0.05 (5\%), sehingga residual untuk masing-masing model ARIMA telah memenuhi asumsi white noise. Namun berdasarkan nilai $p$ value uji normalitas, diketahui bahwa hanya model ARIMA $(2,1,1)$ dan ARIMA $(2,1,0)$ yang memenuhi asumsi distribusi Normal. Selanjutnya, dari beberapa model tentatif dilakukan pemilihan model terbaik berdasarkan nilai Akaike's Information Criterion (AIC), Schwartz Bayesian Criterion (SBC), dan Mean Square Error (MSE) pada Tabel 4 berikut.

Tabel 4 menunjukkan bahwa model ARIMA $(2,1,1)$ merupakan model terbaik dan layak digunakan untuk peramalan karena memiliki nilai AIC dan SIC terkecil dibandingkan model ARIMA lainnya.

Tabel 3. Pengujian Residual Model

\begin{tabular}{|c|c|c|c|c|}
\hline \multirow{2}{*}{ Model } & \multicolumn{2}{|c|}{ Uji White noise } & \multicolumn{2}{c|}{ Uji Normalitas } \\
\cline { 2 - 5 } & $P$-value & Keputusan & $P$-value & Keputusan \\
\hline ARIMA (2,1,1) & 0,438 & White noise & $>0,15$ & Normal \\
\hline ARIMA (2,1,0) & 0,567 & White noise & 0,038 & Normal \\
\hline ARIMA (1,1,1) & 0,697 & White noise & $<0,01$ & Tidak Normal \\
\hline ARIMA (1,1,0) & 0,764 & White noise & $<0,01$ & Tidak Normal \\
\hline ARIMA (0,1,1) & 0,739 & White noise & $<0,01$ & Tidak Normal \\
\hline
\end{tabular}

Tabel 4. Nilai AIC, SBC, dan MSE Model ARIMA Deret Input Jumlah Perusahaan

\begin{tabular}{|c|c|c|c|}
\hline Model & AIC & SIC & MSE \\
\hline ARIMA $(2,1,1)$ & 9,9060 & 10,089 & 3741,3 \\
\hline ARIMA $(2,1,0)$ & 11,453 & 11,500 & 3640,4 \\
\hline ARIMA $(1,1,1)$ & 11,211 & 11,307 & 4071,9 \\
\hline ARIMA $(1,1,0)$ & 11,362 & 11,410 & 3977,1 \\
\hline ARIMA $(0,1,1)$ & 13,270 & 13,319 & 3873,5 \\
\hline
\end{tabular}


Berikut merupakan mode ARIMA $(2,1,1)$ untuk deret input jumlah perusahaan.

$$
\begin{gathered}
X_{t}=2,098 X_{t-1}+1,545 X_{t-2}-0,447 X_{t-3} \\
+a_{t}-0,968 a_{t-1}
\end{gathered}
$$

3. Identifikasi Model Deret Input Jumlah Investasi

Berikut merupakan tahapan-tahapan identifikasi model ARIMA untuk deret input jumlah investasi. Tahapan pertama adalah penentuan ordo model ARIMA berdasarkan plot ACF dan PACF di Gambar

\begin{tabular}{|c|c|c|c|c|c|c|c|c|c|}
\hline \multicolumn{3}{|c|}{ Autocorrelation } & \multicolumn{2}{|c|}{ Partial Correlation } & \multicolumn{2}{|r|}{$A C$} & PAC & Q-Stat & Prob \\
\hline 1 & り & 1 & り & 1 & 1 & 0.209 & 0.209 & 0.8827 & 0.347 \\
\hline 1 & & 1 & t & 1 & 2 & -0.021 & -0.068 & 0.8922 & 0.640 \\
\hline 1 & & 1 & 1 & 1 & 3 & 0.011 & 0.031 & 0.8949 & 0.827 \\
\hline 1 & d & 1 & 1 & 1 & & -0.051 & -0.065 & 0.9604 & 0.916 \\
\hline 1 & & 1 & 1 & 1 & & -0.059 & -0.033 & 1.0535 & 0.958 \\
\hline 1 & 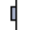 & 1 & 1 & 1 & & -0.059 & -0.047 & 1.1550 & 0.979 \\
\hline 1 & d & 1 & d & 1 & 7 & -0.087 & -0.071 & 1.4014 & 0.986 \\
\hline 1 & c & 1 & 1 & 1 & 8 & -0.085 & -0.060 & 1.6605 & 0.990 \\
\hline 1 & c & 1 & 1 & 1 & 9 & -0.073 & -0.056 & 1.8744 & 0.993 \\
\hline I & 다 & 1 & 10 & 1 & 10 & -0.115 & -0.106 & 2.4829 & 0.991 \\
\hline 1 & C & 1 & 10 & 1 & 11 & -0.121 & -0.100 & 3.2700 & 0.987 \\
\hline 1 & d & 1 & 10 & 1 & 12 & -0.096 & -0.088 & 3.8614 & 0.986 \\
\hline
\end{tabular}
5 .

Gambar 5. Plot ACF dan PACF Deret Input Jumlah Investasi

Berdasarkan Gambar 5, plot ACF signifikan pada lag ke-1 dan plot PACF signifikan pada lag ke-1, sehingga model tentatif ARIMA yang terbentuk adalah ARIMA $(1,0,1), \quad \mathrm{AR}(1)$, dan $\mathrm{MA}(1)$. Berikut merupakan uji residual dari masingmasing model tentatif.

Tabel 5 menunjukkan bahwa semua model tentatif ARIMA memiliki nilai $p$ value lebih dari taraf sinifikansi 0.05 (5\%), sehingga residual untuk masing-masing model ARIMA telah memenuhi asumsi white noise dan berdistribusi Normal. Untuk itu dilakukan pemilihan model terbaik berdasarkan nilai AIC, SIC, dan MSE terkecil.
Berdasarkan Tabel 6, terlihat bahwa model dengan nilai AIC, SIC, dan MSE terkecil adalah ARIMA $(1,0,0)$, sehingga model ini merupakan model tentatif terbaik untuk meramalkan deret input jumlah investasi. Berikut merupakan persamaan model ARIMA $(1,0,0)$ untuk deret input jumlah investasi.

$$
y_{t}=0,270 y_{t-1}+\alpha_{t}
$$

4. Pre-whitening Deret Input dan Output

Prewhitening dilakukan berdasarkan identifikasi model ARIMA pada masingmasing deret input dan deret output. Model prewhitening deret input jumlah perusahaan adalah sebagai berikut.

$$
\begin{aligned}
\alpha_{t}=x_{t}-0,2098 x_{t-1}-1,545 x_{t-2} \\
+0,447 x_{t-3}+0,968 \alpha_{t-1}
\end{aligned}
$$

Dengan cara yang sama, model prewhitening untuk deret input jumlah investasi $\left(\mathrm{y}_{\mathrm{t}}\right)$ adalah sebagai berikut.

$$
\alpha_{t}=y_{t}-0,270 y_{t-1}
$$

Prewhitening deret output elastisitas penyerapan tenaga kerja adalah sebagai berikut.

$$
\begin{aligned}
\beta_{t}= & z_{t}-2,098 z_{t-1}-1,545 z_{t-2}+ \\
& 0,447 z_{t-3}+0,968 \beta_{t-1} \\
\beta_{t}= & z_{t}-0,270 z_{t-1}
\end{aligned}
$$

5. Menghitung Korelasi Silang Antar Variabel

Deret input dan deret output yang telah melalui proses prewhitening, selanjutnya dilakukan perhitungan korelasi silangnya. Nilai dari korelasi silang digunakan untuk mengidentifikasi orde model awal fungsi transfer (b,r,s).

6. Identifikasi Awal Model Fungsi Transfer Identifikasi model awal fungsi transfer dilakukan dengan melihat plot korelasi silang antara deret input dan deret

Tabel 5. Pengujian Residual Model

\begin{tabular}{|c|c|c|c|c|}
\hline \multirow{2}{*}{ Model } & \multicolumn{2}{|c|}{ Uji White noise } & \multicolumn{2}{c|}{ Uji Normalitas } \\
\cline { 2 - 5 } & $P$-value & Keputusan & $P$-value & Keputusan \\
\hline ARIMA (1,0,1) & 0,542 & White noise & $>0,150$ & Normal \\
\hline ARIMA (1,0,0) & 0,552 & White noise & $>0,150$ & Normal \\
\hline ARIMA (0,0,1) & 0,514 & White noise & $>0,150$ & Normal \\
\hline
\end{tabular}

Tabel 6. Nilai AIC, SBC, dan MSE Model ARIMA Deret Input Jumlah Investasi

\begin{tabular}{|c|c|c|c|}
\hline Model & AIC & SBC & MSE \\
\hline ARIMA $(1,0,1)$ & 25,420 & 25,517 & 7,334 \\
\hline ARIMA $(1,0,0)$ & 25,349 & 25,397 & 7,043 \\
\hline ARIMA $(0,0,1)$ & 26,271 & 26,320 & 7,071 \\
\hline
\end{tabular}


output pada Gambar 6. Untuk orde fungsi transfer deret input jumlah perusahan adalah $b=3, r=0$, dan $s=0$. Selanjutnya dilakukan overfitting model untuk memperoleh model fungsi transfer terbaik. Hasil dari kandidat model beserta nilai $R$ squared, RMSE, dan MAPE model dapat dilihat pada Tabel 7 berikut.

(a)

\begin{tabular}{|c|c|c|c|c|c|c|c|}
\hline \multicolumn{5}{|c|}{ ELASTISITAS,JML_PRSH... ELASTISITAS,JJML_PRSH... } & $\mathrm{i}$ & lag & lead \\
\hline 1 & 曰 & 1 & $\boxminus$ & 1 & & 0.2449 & 0.2449 \\
\hline 1 & p & 1 & $\square$ & 1 & & 0.0789 & -0.4188 \\
\hline i & & i & 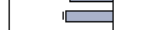 & i & & 0.2768 & -0.4740 \\
\hline 1 & & $\square$ & 18 & 1 & & 0.6148 & -0.2651 \\
\hline 1 & $\Xi$ & & & 1 & & 0.2850 & \\
\hline 1 & 9 & I & & 1 & & & \\
\hline 1 & p & 1 & 1 二 & I & & 0.0981 & -0.1839 \\
\hline I & & $\mathrm{I}$ & 1 只 & 1 & & 0.0 & -0 . \\
\hline 1 & b & & & 1 & & & \\
\hline 1 & G & 1 & 1 & & & 0.0800 & -0.0027 \\
\hline 1 & & 1 & b & 1 & 10 & -0.0060 & 0.1477 \\
\hline 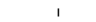 & d & 1 & 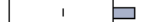 & 1 & 11 & & 0.2250 \\
\hline ' & a & 1 & 曰 & 1 & 12 & -0.1014 & 0.2640 \\
\hline
\end{tabular}

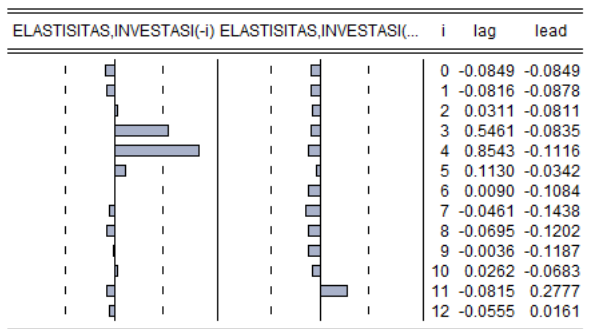

Gambar 6. Korelasi Silang Elastisitas Penyerapan Tenaga Kerja dan (a) Jumlah Perusahaan, (b) Jumlah Investasi

Tabel 7. Identifikasi Model Fungsi Transfer untuk Deret Input Jumlah Perusahaan

\begin{tabular}{|c|c|c|c|}
\hline Model & $\mathrm{R}^{2}$ & RMSE & MAPE \\
\hline $\mathrm{b}=1, \mathrm{~s}=0, \mathrm{r}=0$ & 0,539 & 1,340 & 272,197 \\
\hline $\mathrm{b}=2, \mathrm{~s}=0, \mathrm{r}=0$ & 0,635 & 1,316 & 370,322 \\
\hline $\mathrm{b}=3, \mathrm{~s}=0, \mathrm{r}=0$ & 0,703 & 1,344 & 275,680 \\
\hline $\mathrm{b}=3, \mathrm{~s}=1, \mathrm{r}=0$ & 0,701 & 1,456 & 188,708 \\
\hline $\mathrm{b}=3, \mathrm{~s}=2, \mathrm{r}=0$ & 0,055 & 2,837 & 480,732 \\
\hline $\mathrm{b}=3, \mathrm{~s}=3, \mathrm{r}=0$ & 0,113 & 3,073 & 420,327 \\
\hline
\end{tabular}

Tabel 7 menunjukkan bahwa model fungsi transfer $(3,1,0)$ merupakan model terbaik karena memiliki nilai RMSE dan MAPE terkecil serta memiliki nilai $\mathrm{R}^{2} \mathrm{di}$ atas 0,7. Sehingga model awal fungsi transfer untuk deret input jumlah perusahaan adalah sebagai berikut.

$$
\begin{aligned}
& z_{t}= \frac{\omega(B)}{\delta(B)} x_{t-3}+n_{t} \\
& z_{t}=\left(\omega_{0}-\omega_{0} B\right) x_{t-3}+n_{t} \\
& z_{t}=(0,019-0,014 B) x_{t-3} \\
& \quad+n_{t} \\
& z_{t}=0,019 x_{t-3}-0,014 x_{t-4} \\
&+n_{t}
\end{aligned}
$$

Adapun orde fungsi transfer deret input jumlah investasi adalah $\mathrm{b}=3, \mathrm{r}=2, \mathrm{~s}=1$. Berikut merupakan identifikasi model fungsi transfer terbaik berdasarkan overfitting model.

Tabel 8. Identifikasi Model Fungsi Transfer untuk Deret Input Jumlah Investasi

\begin{tabular}{|c|c|c|c|}
\hline Model & $\mathrm{R}^{2}$ & RMSE & MAPE \\
\hline $\mathrm{b}=1, \mathrm{~s}=1, \mathrm{r}=2$ & 0,746 & 1,040 & 274,348 \\
\hline $\mathrm{b}=2, \mathrm{~s}=1, \mathrm{r}=2$ & 0,890 & 0,730 & 180,418 \\
\hline $\mathrm{b}=3, \mathrm{~s}=1, \mathrm{r}=0$ & 0,951 & 0,512 & 166,262 \\
\hline $\mathrm{b}=3, \mathrm{~s}=2, \mathrm{r}=0$ & 0,974 & 0,395 & 144,327 \\
\hline $\mathrm{b}=3, \mathrm{~s}=3, \mathrm{r}=0$ & 0,975 & 0,420 & 129,379 \\
\hline $\mathrm{b}=3, \mathrm{~s}=0, \mathrm{r}=1$ & 0,981 & 0,305 & 77,3470 \\
\hline $\mathrm{b}=3, \mathrm{~s}=1, \mathrm{r}=2$ & 0,423 & 0,363 & 141,989 \\
\hline
\end{tabular}

Tabel 8 menunjukkan bahwa model fungsi transfer $(3,0,1)$ memiliki nilai MAPE dan RMSE terkecil, serta memiliki nilai $\mathrm{R}^{2}$ tertinggi. Sehingga model awal fungsi transfer untuk deret input jumlah investasi adalah sebagai berikut.

$$
z_{t}=0,000007763 y_{t-3}+n_{t}
$$

Setelah diperoleh model awal fungsi transfer untuk masing-masing deret input, dilakukan pendugaan model awal fungsi transfer bersama antara $x_{t}, y_{t}$, dan $z_{t}$. Sehingga model fungsi transfer input ganda awal adalah sebagai berikut.

$$
\begin{aligned}
z_{t}=0,019 x_{t-3}-0,014 x_{t-4} \\
+0,000007763 y_{t-3}+n_{t}
\end{aligned}
$$

7. Identifikasi Noise Function

Model fungsi transfer input ganda awal selanjutnya digunakan untuk menghitung noise function $\left(n_{t}\right)$ dari model. Namun sebelumnya, dilakukan pengujian asumsi residual white noise dan

Tabel 9. Uji Asumsi Deret Noise

\begin{tabular}{|l|c|c|c|c|}
\hline \multirow{2}{*}{ Deret Input } & \multicolumn{2}{c|}{ Uji White Noise } & \multicolumn{2}{c|}{ Uji Normalitas } \\
\cline { 2 - 5 } & $P$-value & Keterangan & P-value & Keterangan \\
\hline Jumlah Perusahaan & 0,732 & White noise & 0,233 & Normal \\
\hline Jumlah Investasi & 0,283 & White noise & 0,068 & Normal \\
\hline
\end{tabular}


berdistribusi Normal dengan hasil sebagai berikut.

Tabel 9 menunjukkan bahwa deret noise telah memenuhi asumsi white noise dan berdistribusi Normal untuk masingmasing deret input. Selanjutnya, dilakukan penghitungan nilai $n_{t}$ dengan melakukan transformasi terhadap model awal, sehingga diperoleh persamaan berikut.

$$
\begin{array}{r}
n_{t}=z_{t}-0,019 x_{t-3}+0,014 x_{t-4} \\
-0,000007763 y_{t-3}
\end{array}
$$

Dari noise function tersebut selanjutnya dilakukan identifikasi model ARIMA dari deret sisaan dengan beberapa alternatif model sebagai berikut.

Tabel 10 menunjukkan bahwa model ARIMA $(1,0,1)$ merupakan model terbaik yang memiliki nilai MAPE dan RMSE kecil serta memiliki nilai $\mathrm{R}^{2}$ yang tinggi, sehingga model ARIMA deret sisaannya adalah sebagai berikut.

$$
\begin{aligned}
\phi_{p}(B) n_{t} & =\theta_{q}(B) \alpha_{t} \\
n_{t} & =\frac{\theta_{q}(B)}{\phi_{p}(B)} \alpha_{t} \\
n_{t} & =\frac{(1-0,966 B)}{(1-0,999 B} \alpha_{t}
\end{aligned}
$$

8. Pendugaan Akhir Model Fungsi Transfer Identifikasi model akhir fungsi transfer dilakukan dengan mengkombinasikan model awal fungsi transfer input ganda dengan model ARIMA deret sisaan. Berikut merupakan model fungsi transfer yang diperoleh.

$$
\begin{aligned}
z_{t}=0.019 x_{t-3} & -0.014 x_{t-4} \\
+ & 0.000007763 y_{t-3} \\
+ & \frac{(1-0.966 B)}{(1-0.999 B)} \alpha_{t}
\end{aligned}
$$

Berdasarkan model tersebut, dapat diketahui bahwa elastisitas penyerapan tenaga kerja subsektor perikanan pada tahun ke- $t$ dipengaruhi oleh selisih perkembangan jumlah perusahaan pada tiga tahun (dengan koefisien 0,019) dan empat tahun (dengan koefisien -0,014) sebelum tahun $\mathrm{t}$, dengan asumsi nilai dari variabel lain tetap. Dengan persamaan tersebut, elastisitas penyerapan tenaga kerja subsektor perikanan di tahun ke- $t$ akan tergolong elastis jika jumlah perusahaan subsektor perikanan di atas 200 perusahaan dengan asumsi tidak ada selisih jumlah perusahaan di tahun ke $t-3$ dan $t-4$. Hasil penelitian mengenai pengaruh perkembangan jumlah perusahaan perikanan terhadap penyerapan tenaga kerja juga dikemukakan oleh Napitupulu (2016) yang menjelaskan bahwa dari 8 variabel prediktor yang mem-pengaruhi penyerapan tenaga kerja baik perikanan tangkap maupun budidaya, 3 diantaranya signifikan dan memberikan pengaruh positif, yaitu nilai produksi, jumlah kapal, dan jumlah perusahaan perikanan. Untuk itu, strategi pengembangan subsektor perikanan agar dapat berkontribusi terhadap penyerapan tenaga kerja dapat dilakukan dengan menambah nilai produksi perikanan, jumlah kapal penangkap ikan, dan jumlah perusahaan perikanan tangkap dan budidaya.

Selain jumlah perusahaan perikanan, elastisitas penyerapan tenaga kerja pada tahun ke- $t$ juga dipengaruhi oleh perkembangan jumlah investasi tiga tahun sebelum tahun ke- $t$ dengan koefisien 0,000007763 , artinya elastisitas penyerapan tenaga kerja di tahun ke- $t$ akan memiliki kategori elastis jika perkembangan jumlah investasi di tahun t-3 sebesar 129 milyar atau lebih, dengan asumsi variabel lain bernilai tetap. Beberapa hasil penelitian juga menyatakan pengaruh positif jumlah investasi terhadap penyerapan tenaga kerja, diantaranya adalah penelitian oleh Luhur, dkk (2014) yang menyatakan bahwa kebijakan meningkatkan investasi pada sektor industri perikanan melalui pembangunan dan per-baikan infrastruktur, institusi, dan sumber daya manusia bisa menjadi salah satu fokus kebijakan untuk mendorong kinerja yang lebih baik pada

Tabel 10. Identifikasi Model ARIMA Deret Sisaan

\begin{tabular}{|c|c|c|c|c|c|}
\hline Deret Input & Deret inputt & Model tentatif & $\mathrm{R}^{2}$ & RMSE & MAPE \\
\hline $\mathrm{b}=3$ & $\mathrm{~b}=3$ & ARIMA $(1,0,0)$ & 0,860 & 1,164 & 329,814 \\
\cline { 2 - 6 } $\mathrm{s}=1$ & $\mathrm{~s}=0$ & ARIMA $(0,0,1)$ & 0,856 & 1,178 & 324,437 \\
\cline { 3 - 6 } $\mathrm{r}=0$ & $\mathrm{r}=1$ & ARIMA $(1,0,1)$ & 0,874 & 1,274 & 191,679 \\
\hline
\end{tabular}


usaha perikanan. Penelitian lain oleh Putra (2011) menjelaskan bahwa penambahan investasi sebesar 100 milyar rupiah pada sektor perikanan berdampak pada peningkatan total output perekonomian yang juga menyebabkan adanya tambahan terhadap kebutuhan tenaga kerja total sekitar 78,6\%.

\section{Proyeksi Penyerapan Tenaga Kerja Subsektor Perikanan Nasional}

Setelah memperoleh model akhir fungsi trasfer, dilakukan penghitungan proyeksi deret output elastisitas penyerapan tenaga kerja tahun 2019-2024 dengan hasil sebagai berikut.

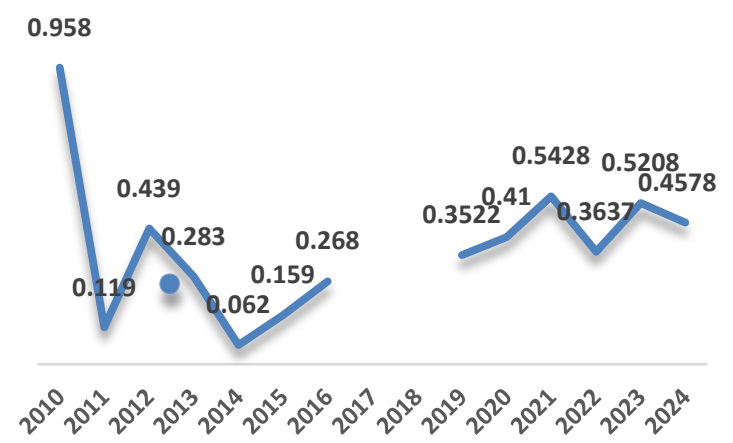

Gambar 7. Perkembangan Indeks Elastisitas Penyerapan Tenaga Kerja

Dari tahun 2010 hingga 2016, pertumbuhan ekonomi subsektor perikanan memang cukup baik, berkisar antara 5$7,8 \%$. Namun, pertumbuhan ekonomi yang baik tersebut tidak diimbangi dengan penyerapan tenaga kerja yang baik juga, karena nilai median elastisitas penyerapan tenaga kerja di tahun 2010-2016 hanya sebesar 0,268. Hal ini menjadikan elastisitas penyerapan tenaga kerja subsektor perikanan tergolong inelastis. Dengan indeks elastisitas tersebut, maksimum tenaga kerja yang dapat terserap pada subsektor perikanan sejumlah 100 ribu pekerja setiap tahunnya.

Meskipun demikian, Gambar 7 menunjukkan bahwa indeks elastisitas penyerapan tenaga kerja di tahun 20192024 cenderung mengalami pertumbuhan dibanding tahun-tahun sebelumnya. Forecast elastisitas penyerapan tenaga kerja menunjukkan angka yang berfluktuasi antara 0,35-0,55. Koefisien elastisitas untuk masing-masing tahun adalah positif yang menunjukkan bahwa laju pertumbuhan PDB dan penyerapan tenaga kerja subsektor perikanan akan mengalami peningkatan setiap tahunnya. Namun, karena kategori elastisitas tergolong inelastis, maka pertumbuhan ekonomi di tahun 2019-2024 tidak terlalu mendorong respon pertumbuhan penyerapan tenaga kerja subsektor perikanan. Subsektor ini akan mengalami peningkatan rata-rata penyerapan tenaga kerja setiap tahunnya, yaitu sekitar 120-180 ribu tenaga kerja dari setiap $1 \%$ pertumbuhan ekonomi di sektor ini.

Angka elastisitas ini sebenarnya jauh di bawah target yang telah ditetapkan pemerintah. Tahun 2016, pemerintah menargetkan angka elastisitas sebanyak 350 ribu serapan tenaga kerja dari setiap $1 \%$ pertumbuhan ekonomi, karena pemerintah berkeyakinan terhadap prospek perekonomian yang membaik dan implementasi program pemerintah yang bertumpu pada sektor padat karya. Namun, meskipun realisasi indeks elastisitas meleset, elastisitas penyerapan tenaga kerja tetap menjadi salah satu tolok ukur pertumbuhan berkualitas dalam masa pemerintahan 2014-2019 (Baihaqi, 2016).

Dalam pelaksanaan industrialisasi perikanan yang bertujuan untuk mengoptimalkan pemanfaatan potensi SDA perikanan dan penyerapan tenaga kerja subsektor perikanan dan kelautan, ada tiga aktor yang menjadi triple bottom line, yaitu pemerintah sebagai pembuat kebijakan, pelaku industri/perusahaan, serta pekerja. SDA perikanan \& kelautan dimiliki dan dikelola atas nama rakyat oleh pemerintah, sehingga tujuan ekonomi dalam kerangka kerja perikanan mengharuskan pemerintah untuk memastikan manfaat ekonomi sumber daya perikanan dimaksimalkan. Untuk itu, pemerintah perlu memprioritaskan langkah-langkah manajemen yang selaras dengan tujuan ekonomi dengan melibatkan kelompok kepentingan khusus, yaitu industri perikanan dan investor (Laxe, Bermudez, dan Palmero, 2018). 
Investasi menjadi salah satu langkah strategis untuk mengembangkan industrialisasi subsektor perikanan dari hulu sampai hilir. Penciptaan industri di hulu sampai hilir tentunya harus mempertimbangkan keteram-pilan yang tersedia secara lokal. Untuk itu, perlu dibuat kebijakan bertingkat dari lokal, regional, hingga nasional untuk menyesuaikan perbedaan geografis dalam struktur dan komposisi lapangan kerja subsektor perikanan dan kelautan (Putten, Cvitanovic, dan Fulton, 2016). Lebih lanjut, kebijakan di bidang investasi dan industri perikanan dan kelautan harus didasarkan pada partisipasi dan transparansi untuk mendukung penerapan strategi tata kelola sumber daya perikanan dan kelautan. Kebijakan yang memadai dan pelibatan aktor ini selanjutnya akan mengarahkan pada pencapaian pertumbuhan ekonomi (Emery dkk, 2017). Dengan demikian, PDB yang menjadi salah satu indikator pertumbuhan ekonomi perikanan bisa meningkat dan secara tidak langsung akan meningkatkan penyerapan tenaga kerja di subsektor ini.

\section{KESIMPULAN}

Hasil proyeksi elastisitas penyerapan tenaga kerja subsektor perikanan menggunakan metode fungsi transfer multi input dengan pertumbuhan jumlah perusahaan perikanan dan perkembangan jumlah investasi sebagai deret input menunjukkan bahwa di tahun 2019-2024 elastisitas penyerapan tenaga kerja lebih banyak masuk dalam kategori inelastis dengan penyerapan sebesar 120-180 ribu tenaga kerja dari setiap $1 \%$ pertumbuan ekonomi. Untuk itu, diperlukan strategi pengembangan subsektor perikanan agar dapat berkontribusi terhadap penyerapan tenaga kerja, salah satunya adalah dengan meningkatkan jumlah dan skala industri perikanan tangkap dan budidaya agar memiliki nilai tambah yang lebih tinggi. Pembinaan hubungan antar entitas sesama industri pada semua tingkatan juga diperlukan untuk mendorong kemitraan usaha yang saling menguntungkan melalui pengembangan komoditas nasional dan produk-produk inovtasi dan kompetitif di pasar global. Selain itu, kebijakan meningkatkan investasi pada sektor industri perikanan melalui pembangunan dan perbaikan infrastruktur, institusi, dan sumber daya manusia bisa menjadi salah satu fokus kebijakan untuk mendorong kinerja yang lebih baik pada usaha perikanan.

\section{DAFTAR PUSTAKA}

Baihaqi, M. (2016, 01 27). Target Elastisitas Penyerapan Tenaga Kerja Dipertahankan. (Harian Ekonomi Neraca) Dipetik 09 09, 2019, dari http://www.neraca.co.id/article/ 64765/target-elastisitas-penyerapantenaga-kerja-dipertahankan

Bappenas. (2016). Kajian Strategis Industrialisasi Perikanan Untuk Mendukung Pembangunan Ekonomi Wilayah. Jakarta: Bappenas.

BPS. (2015). Keadaan Angkatan Kerja di Indonesia 2015. Jakarta: Badan Pusat Statistik. Diambil kembali dari https://

www.bps.go.id/publication/2015/11/ 30/311dc33e7624d47529ec4800/kea daan-angkat an-kerja-di-indonesiaagustus-2015.html

BPS. (2017). Produk Domestik Bruto (PDB) Atas Dasar Harga Konstan Menurut Lapangan Usaha. Dipetik Mei 2018, 07, dari Badan Pusat Statistik (BPS): https://www.bps.go. $\mathrm{id} /$ statictable/2009/07/02/1200/-seri2000-pdb-atas-dasar-harga-konstan2000-menu rut-lapangan-usahamiliar-rupiah-2000-2014.html

Dumairy. (2004). Matematika Terapan untuk Bisnis dan Ekonomi. Yogyakarta: BPFE.

Emery, T. J., Gardner, C., Hartmann, K., \& Cartwright, I. (2017). Beyond sustainability: is government obliged to increase economic benefit from fisheries in the face industry resistance? Marine Policy, 76, 48-54. doi:https://doi.org/10.1016/j.marpol. 2016.11.018

FAO. (2012). The State of World Fisheries and Aquaculture. Rome: Food and 
Agriculture Organization of The United States.

Hakim, M. (2009). Industrialisasi Di Indonesia : Menuju Kemitraan yang Islami. Jurnal Hukum Islam, 7(1), 106-121.

Huda, H. M., Purnamadewi, Y. L., \& Firdaus, M. (2015). Industrialisasi Perikanan Dalam Pengembangan Wilayah Jawa Timur. Jurnal Tata Loka, 17(2), 99-112.

Junaidi dan Zulfanetti. (2016). Analisis Kondisi dan Proyeksi

Ketenagakerjaan Di Provinsi Jambi. Jurnal Perspektif Pembiayaan dan Pembangunan Daerah, 3(3), 141150.

doi:https://doi.org/10.22437/ppd.v3i3 .3516

Kementerian Pertanian. (2013). Analisis dan Proyeksi Tenaga Kerja Sektor Pertanian 2013-2019. Jakarta: Sekretariat Jenderal Kementerian Pertanian Republik Indonesia.

KKP. (2012). Pedoman Umum Industrialisasi Kelautan dan Perikanan. Jakarta: Kementerian Kelautan dan Perikanan Republik Indonesia. Diambil kembali dari http://jdih.kkp.go.id/peraturan/per27-men-2012.pdf

KKP. (2012). Peraturan Menteri Kelautan dan Perikanan No.27 Tahun 2012 Tentang Pedoman Umum Industrialisasi Kelautan dan Perikanan Indonesia.

Kominfo. (2018). Menuju Poros Maritim Dunia. Dipetik Juli 15, 2018, dari Kementerian Komunikasi dan Informatika Republik Indonesia: https://www.kominfo.go.id/con tent/detail/8231/menuju-porosmaritim-dun ia/0/kerja_nyata

Kumalasari, R. (2012). Analisis Proyeksi Tenaga Kerja Daerah di Kabupaten Magetan Tahun 2011-2014. Surakarta: Penerbit Universitas Sebelas Maret.

Laxe, F. G., Bermudez, F. M., \& Palmero, M. F. (2018). Governance of the fishery industry: A new global context. Ocean and Coastal
Management, $\quad 153$

doi:https://doi.org

/10.1016/j.ocecoaman.2017.12.009

Makridakis, H. (1999). Forcasting Methods and Its Application. Jakarya: Binarupa Aksara.

Mariza, N., Wicaksono, B., \& Octavia, J. (2016). Kebijakan Percepatan Pembangunan Industri Perikanan Nasional. Jakarta: Center for Public Policy Transformation.

Mongabay. (2018). Kapan Industri Perikanan Nasional Kuat Lagi ? Dipetik 15 Juli, 2018, dari http://www.mongabay.co.id/2018/06/ 14/kapan-industri-perikanannasional-kuat-lagi/

Musyaffa, A. (2018). Potensi Pemanfaatan Laut Indonesia Belum Optimal. Dipetik Mei 2018, 07, dari https://www.aa.com.tr/id/

ekonomi/kadin-pemanfaatan-potensilaut-in donesia-belummaksimal/1027120

Poernomo, A., \& Heruwati, E. S. (2011). Industrialisasi Perikanan : Suatu Tantangan Untuk Perubahan. Squalen, 6(3), 87-94.

Pusat Data dan Informasi Pertanian. (2013). Analisis dan Proyeksi Tenaga Kerja Sektor Pertanian 2013-2019. Jakarta: Sekretariat Jenderal Kementerian Pertanian Republik Indonesia.

Pusat Data Statistik dan Informasi. (2015). Kelautan dan Perikanan Dalam Angka. Jakarta: Kementerian Kelautan dan Perikanan Republik Indonesia.

Pusat Data Statistik dan Informasi. (2018). Kelautan dan Perikanan Dalam Angka 2018. Diambil kembali dari Kementerian Kelautan dan Perikanan Republik Indonesia: https://kkp.go.id/setjen/satudata/page /1453-kelautan-dan-perikanandalam-angka

Putten, I., Cvitanovic, C., \& Fulton, E. (2016). A changing marine sector in Australian coastal communities: An analysis of inter and intra sectoral industry connections and employment. Ocean \& Coastal 
Management, $\quad 131, \quad$ 1-12. doi:https://doi.org/

10.1016/j.ocecoaman.2016.07.010

Republik Indonesia. (2016). Instruksi

Presiden Nomor 7 Tahun 2016

Mengenai Percepatan Pembangunan Industri Perikanan Nasional. Jakarta: Sekretariat Negara.

Republik Indonesia. (2017). Peraturan Presiden Nomor 3 Tahun 2017 Mengenai Rencana Aksi Percepatan Pembangunan Industri Perikanan Nasional. Jakarta: Sekretariat Negara.

Subri, M. (2007). Ekonomi Kelautan. Jakarta: PT. Raja Grafindo Persada.

Wei, W. (2006). Time Series Analysis. United States of America: Pearson Addison Wisley. 